В.В. Скиба ${ }^{1,3,4}$, В.Ф. Рибальченко ${ }^{2,3}$, О.В. Іванько ${ }^{1,3,4}$, Р.М. Борис ${ }^{3}$, Дар Ясін Ахмед ${ }^{3}$, В.В Лисиця ${ }^{3,4}$ Еволюція діагностики та хірургічного лікування
хворих на інтраабдомінальні інфільтрати й абсцеси
первинного та післяопераційного походження

${ }^{1}$ Національний медичний університет імені О.О. Богомольия, м. Київ, Україна

${ }^{2}$ Національний університет охорони здоров'я України імені П.Л. Шупика, м. Київ, Україна

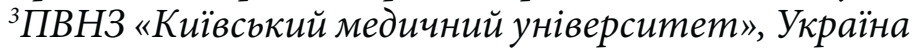

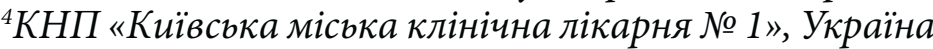

Paediatric surgery.Ukraine.2021.3(72):15-29; doi 10.15574/PS.2021.72.15

For citation: Skyba VV, Rybalchenko VF, Ivanko AV, Borys RM, Dar Yasinya Akhmed, Lysytsa VV. (2021). Evolution of diagnosis and surgical treatment of intraabdominal infiltrates, abscesses of primary and postoperative origin in patients. Paediatric Surgery.Ukraine. .3(72):15-29; doi 10.15574/PS.2021.72.15.

Мета - поліпшити результати хірургічного лікування хворих з інтраабдомінальними інфільтратами й абсцесами за рахунок впровадження інформативних методів візуалізації та хірургічних технологій.

Матеріали та методи. У клініці кафедри хірургічних хвороб № 1 на базі центру хірургії Київської міської клінічної лікарні № 1 у період 2006-2019 рр. перебували на лікуванні 218 пацієнтів із первинними та вторинними інтраабдомінальними інфільтратами й абсцесами. Вік пацієнтів становив від 16 до 85 років. Серед пацієнтів було 107 (49,08\%) чоловіків і 11 (50,92\%) жінок. Залежно від часу шпиталізації (по роках) хворих поділено на дві групи: контрольна група (2006-2012 рр.) - 117 (53,67\%) хворих; досліджувана група (20132019 рр.) - 101 (46,33\%) хворий. У досліджуваній групі використано візуалізаційні технології та вдосконалені методики хірургічного лікування.

Результати. Хворих поділено на дві групи залежно від розвитку недуги та проведення лікування: первинні інфільтрати й абсцеси - у 191 (87,61\%), вторинні післяопераційні - у 27 (12,39\%) осіб. Причинами виникнення первинних інфільтратів й абсцесів були: ускладнені форми апендициту - у 74 (33,94\%), перфоративна виразка шлунка і дванадцятипалої кишки - у 48 (22,02\%), ускладнені форми холециститу у 69 (31,65\%) пацієнтів. Післяопераційні інфільтрати й абсцеси відмічалися у 27 (12,39\%) хворих, які перенесли ургентні операції: адгеолізис спайкової непрохідності - у $14(6,42 \%)$, ускладнені грижі різної локалізації - у 13 (5,97\%). Післяопераційні ускладнення діагностувалися у 43 (19,72\%) хворих, з яких із боку операційної рани - у 34 (15,59\%), черевної порожнини - у 29 (15,18\%), ці ускладнення потребували релапаротомії чи лапароскопії: при деструктивному апендициті - у 10 (13,51\%), перфоративній виразці шлунка та дванадцятипалої кишки - у 6 (12,5\%), деструктивному холециститі - у $9(13,04 \%)$, спайковій кишковій непрохідності - у 13 (19,12\%) з 68, защемлених та ускладнених грижах - у 14 (17,28\%) з 81 обстежених хворих. Під час релапаротомії неспроможність стінки кишки та кишкових швів встановлено в 11332 пацієнтів, накладено ілеостому в 7, а цекостому - в 1 хворого. У контрольній групі померло 8 (6,84\%) хворих на тлі продовжуваного перитоніту, тромбозу мезентеріальних судин та поліорганної недостатності й супутніх хвороб, а в досліджуваній - 4 (3,96\%) хворі.

Висновки. Хірургічне лікування $є$ індивідуальним залежно від недуги. Так, при деструктивному апендициті 374 (38,74\%) осіб лапаротомію виконано 42 (21,99\%), лапароскопію - 32 (16,75\%), a 12 (6,28\%) пацієнтам - із конверсією; при перфоративній виразці шлунка та дванадцятипалої кишки проведено відкриту лапаротомію у 48 (25,13\%); при холециститі 369 (36,13\%) хворих лапаротомію проведено 48 (25,13\%), а лапароскопію - 21 (11,00\%) особі. Застосування візуалізаційних і лікувальних технологій - допплерографії, гідроструменевого скальпеля та лапароскопії у 64 (33,51\%) - дало змогу отримати кращі близькі і віддалені результати з урахуванням якості життя та знизити рівень післяопераційної летальності з 6,84\% до 3,96\% (середній показник - 5,5\%). 
Дослідження виконано відповідно до принципів Гельсінської декларації. Протокол дослідження ухвалено Локальним етичним комітетом зазначених установ. На проведення досліджень отримано інформовану згоду пацієнтів.

Автори заявляють про відсутність конфлікту інтересів.

Ключові слова: деструктивний апендицит, холецистит, перфоративна виразка шлунка та дванадцятипалої кишки, спайкова непрохідність, защемлені грижі, діагностика та лікування.

\section{Evolution of diagnosis and surgical treatment of intra-abdominal infiltrates, abscesses of primary and postoperative origin in patients \\ V.V. Skyba ${ }^{1,3,4}$, V.F. Rybalchenko ${ }^{2,3}$, A.V. Ivanko ${ }^{1,3,4}$, R.M. Borys ${ }^{3}$, Dar Yasinya Akhmed ${ }^{3}$, V.V. Lysytsa ${ }^{3,4}$}

${ }^{1}$ A.A. Bogomolets National Medical University, Kyiv, Ukraine

${ }^{2}$ Shupyk National Healthcare University of Ukraine, Kyiv

${ }^{3}$ Kyiv medical university, Ukraine

${ }^{4}$ Health Medical Center Hospital, Kyiv, Ukraine

Purpose - to improve the results of surgical treatment of patients with intra-abdominal infiltrates and abscesses through the introduction of the latest imaging methods and surgical technologies.

Materials and methods. In the clinic of the Department of Surgical Diseases No 1, on the basis of the Surgery Center of the Kyiv City Clinical Hospital No. 1 from 2006 to 2019218 patients with primary and secondary intra-abdominal infiltrates, abscesses and fluid formations were treated. The patients' age ranged from 16 to 85 years. There were $107(49.08 \%)$ male patients, $111(50.92 \%)$ female patients. Depending on the time of hospitalization (by years), the patients were divided into two groups: the control group (CG) (2006-2012) 117 (53.67\%) patients and the study group (SG) (2013-2019) 101 (46.33\%) patients. The SG used the latest imaging technologies and improved methods of surgical treatment.

Results. The patients were divided into two groups: primary in 191 (87.61\%) and secondary postoperative infiltrates and abscesses in 27 (12.39\%). The causes of primary infiltrates and abscesses were: complicated forms of appendicitis in 74 (33.94\%), perforated stomach and duodenal ulcer in 48 (22.02\%), complicated forms of cholecystitis in 69 (31.65\%). Postoperative infiltrates and abscesses were observed in 27 (12.39\%) patients who underwent urgent surgery: adgeolysis of adhesive ileus in $14(6.42 \%)$ and complicated hernias of various localization in $13(5.97 \%)$. Postoperative complications were diagnosed in $43(19.72 \%)$ patients, of whom $34(15.59 \%)$ from the surgical wound and $29(15.18 \%)$ of the abdominal cavity, who required relaparotomy or laparoscopy, with destructive appendicitis in $10(13.51 \%)$, perforated gastric ulcer and 12 duodenal ulcer in $6(12.5 \%)$, destructive cholecystitis in 9 (13.04\%), adhesive intestinal obstruction in 13 (19.12\%) and with strangulated and complicated hernias in 14 (17.28\%) of the examined patients. During relaparotomy, incompetence of the intestinal wall and intestinal sutures was established in 11 out of 32 patients, an ileostomy was imposed in 7 , and cecostomy in 1 patient. Actually, in the control group, $8(6.84 \%)$ patients died on the background of ongoing peritonitis, thrombosis of mesenteric vessels and multiple organ failure and concomitant ailments and in the study group 4 (3.96\%) patients died.

Conclusions. Surgical treatment is individualized depending on the disease, so with destructive appendicitis from 74 (38.74\%) laparotomic in 42 (21.99\%), laparoscopic in $32(16.75 \%)$, and in $12(6.28 \%)$ with conversion; perforated gastric ulcer and duodenal ulcer in 48 (25.13\%) open laparotomy; with cholecystitis of $69(36.13 \%)$ patients, $48(25.13 \%)$ had laparotomy and $21(11.00 \%)$ had laparoscopic examination. The use of the latest imaging and treatment technologies: Doppler ultrasonography, hydrojet scalpel and laparoscopy in 64 (33.51\%), allowed to have better near and long-term results and to reduce postoperative mortality from $6.84 \%$ to $3.96 \%$, with an average of $5.5 \%$.

The research was carried out in accordance with the principles of the Helsinki declaration. The study protocol was approved by the Local Ethics Committee of these Institutes. The informed consent of the patient was obtained for conducting the studies.

The authors declare no conflicts of interests.

Key words: destructive appendicitis, cholecystitis, perforated gastric ulcer and 12-duodenal ulcer, adhesive leakage, strangulated hernias, diagnosis and treatment.

\section{Эволюция диагностики и хирургического лечения больных интраабдоминальными инфильтратами и абсцессами первичного и послеоперационного происхождения \\ В.В. Скиба ${ }^{1,3,4}$, В.Ф. Рыбальченко 2,3 А.В. Иванько ${ }^{1,3,4}$, Р.Н. Борис ${ }^{3}$, Дар Ясиня Ахмед ${ }^{3}$, В.В. Лисиця ${ }^{3,4}$}

${ }^{1}$ Национальный медицинский университет имени А.А. Богомольца, г. Киев, Украина

${ }^{2}$ Национальный университет здравоохранения Украины имени П.Л. Шупика, г. Киев

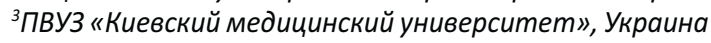

${ }^{4}$ КНП «Киевская городская клиническая больница № 1», Украина

Цель - улучшить результаты хирургического лечения больных с интраабдоминальными инфильтратами и абсцессами за счет внедрения новейших методов визуализации и хирургических технологий.

Материалы и методы. В клинике кафедры хирургических болезней № 1 на базе центра хирургии Киевской городской клинической больницы № 1 в период 2006-2019 гг. проходили лечение 218 пациентов с первичными и вторичными интраабдоминальными инфильтратами и абсцессами. Возраст пациентов составил от 16 до 85 лет. Среди больных было 107 (49,08\%) мүжчин и 111 (50,92\%) женщин. В зависимости от времени госпитализации (по годам) больные поделены на две группы: контрольная группа (2006-2012 гг.) - 117 (53,67\%) лиц, исследуемая группа (20132019 гг.) - 101 (46,33\%) больной. В исследуемой группе использованы информативные визуализационные технологии и усовершенствованные методики хирургического лечения.

Результаты. Больные поделены на две группы в зависимости от развития болезни и проведения лечения: первичные инфильтраты и абсцессы у 191 (87,61\%), вторичные послеоперационные - у 27 (12,39\%). Причинами возникновения первичных инфильтратов и абсцессов были: осложненные формы аппендицита - у 74 (33,94\%), перфоративная язва желудка и двенадцатиперстной кишки - у 48 (22,02\%), осложненные формы холецистита - у 69 (31,65\%) лиц. Послеоперационные инфильтраты и абсцессы наблюдались у 27 (12,39\%) больных, перенесших ургентные операции: адгеолизис спаечной непроходимости - 14 (6,42\%), осложненные грыжи различной локализации - 13 (5,97\%). Послеоперационные 
осложнения диагностировались у 43 (19,72\%) больных, из них со стороны операционной раны -у 34 (15,59\%), брюшной полости - у 29 (15,18\%), требовавшие проведения релапаротомии или лапароскопии, при деструктивном аппендиците -у 10 (13,51\%), перфоративной язве желудка и двенадцатиперстной кишки - у 6 (12,5\%), деструктивном холецистите - у 9 (13,04\%), спаечной кишечной непроходимости - у 13 (19,12\%) с 68, при ущемленных и осложненных грыжах - у 14 (17,28\%) с 81 обследованных больных. Во время релапаротомии несостоятельность стенки кишки и кишечных швов установлена у 11 из 32 пациентов, наложена илеостома - у 7, а цекостома - у 1 больного. В контрольной группе умерло 8 (6,84\%) больных на фоне продолжающегося перитонита, тромбоза мезентериальных сосудов и полиорганной недостаточности и сопутствующие недугов, а в исследовательской группе $-4(3,96 \%)$ больных.

Выводы. Хирургическое лечение является индивидуальным в зависимости от заболевания. Так, при деструктивном аппендиците из 74 (38,74\%) больных лапаротомия проведена 42 (21,99\%), лапароскопия - 32 (16,75\%), а 12 (6,28\%) пациентам - с конверсией; при перфоративной язве желудка и двенадцатиперстной кишки выполнена открытая лапаротомия 48 (25,13\%); при холецистите из 69 (36,13\%) больных лапаротомия проведена $48(25,13 \%)$, а лапароскопия - $21(11,00 \%)$ больному. Использование визуализационных и лечебных технологий - допплерографии, гидроструйного скальпеля и лапароскопии у 64 (33,51\%) больных - позволило получить лучшие близкие и отдаленные результаты с учетом качества жизни и снизить уровень послеоперационной летальности с 6,84\% до 3,96\% (средний показатель -5,5\%).

Исследование выполнено в соответствии с принципами Хельсинской декларации. Протокол исследования утвержден Локальным этическим комитетом указанных в работе учреждений. На проведение исследований получено информированное согласие пациентов.

Авторы заявляют об отсутствии конфликта интересов.

Ключевые слова: деструктивный аппендицит, холецистит, перфоративная язва желудка и двенадцатиперстной кишки, спаечная непроходимость, ущемленные грыжи, диагностика и лечение.

Інтраабдомінальні інфільтрати й абсцеси становлять від 2\% до 29,6\% в ургентній хірургії та не мають тенденції до зниження. Вони є однією з найактуальніших проблем, особливо в осіб працездатного віку, а це обумовлює соціальну значущість проблеми. Поміж тим, соціально-економічні чинники зумовлюють пізнє звернення по допомогу, а це, своєю чергою, призводить до формування абсцесів й інфільтратів черевної порожнини у хворих від 20,5\% до $25 \%[4,7-10,15,17]$.

За даними П.Д. Фоміна і співавт. (2018), в Україні пізніше 24 год від початку захворювання госпіталізують пацієнтів: із деструктивним апендицитом (ДА) - 20,9\% (при післяопераційній летальності $0,15 \%)$; із гострим холециститом - 38,1-39,2\% (при післяопераційній летальності в середньому 16,3$19,7 \%)$; із перфоративною гастродуоденальною виразкою - 12,5\% (при післяопераційній летальності $13,73 \%)$; із гострою непрохідністю кишечника - 5\%, а серед гострих хірургічних захворювань черевної порожнини грижі живота у 3-4\% усього населення з частотою ускладнень - утисків у 3-27\% хворих [4]. За літературними даними, післяопераційні абсцеси розвиваються в $0,8-2 \%$ оперованих хворих при летальності 10,5-26\%. При цьому внутрішньочеревні абсцеси й інфільтрати посідають друге місце серед причин релапаротомії в ранньому післяопераційному періоді $[4,7,10]$. Поміж тим, післяопераційні ускладнення $є$ значною проблемою як прогнозування перебігу, так і хірургічного лікування невідкладних станів органів черевної порожнини. За даними Olanrewaju Samuel Balogun та співавт. (2019), іхх кількість становить $28,5 \%$ із такими ускладненнями, як нагноєння операційної рани $(18,6 \%, 3$ розбіжністю у $15,2 \%)$ й інтраабдомінальні абсцеси $(13,5 \%)$ [2]. Так, Varut Lohsiriwat та співавт. (2009) вказує на те, що при перфоративній виразковій хворобі частота ускладнень дорівнює 30\% [6]. F. Ausania та співавт. (2015) зазначає, що перфорація жовчного міхура становить $2-11 \%$ із показником захворюваності 57,7\% [1].

Таким чином, вищезазначене підкреслює необхідність подальшого вивчення цієї патології як із метою прогнозування перебігу хвороби, так і адекватного хірургічного лікування для досягнення зменшення кількості післяопераційних ускладнень і летальності.

Мета дослідження - поліпшити результати хірургічного лікування хворих із первинними та післяопераційними інтраабдомінальними інфільтратами й абсцесами за рахунок впровадження високоінформативних новітніх методів візуалізації та хірургічних технологій.

\section{Матеріали та методи дослідження}

У клініці кафедри хірургічних хвороб № 1, на базі центру хірургії Київської міської клінічної лікарні № 1 у період 2006-2019 рр. перебували на лікуванні 218 пацієнтів із первинними і вторинними інтраабдомінальними інфільтратами, абсцесами і рідинними утвореннями. Вік хворих становив від 16 років до 85 років. Серед пацієнтів було 107 (49,08\%) чоловіків і 111 (50,92\%) жінок. До дослідження залучили хворих, які страждали від пухких інфільтратів, абсцесів і рідинних утворень. До дослідження не залучені пацієнти зі щільними інфільтратами, оскільки відмінна тактика лікування. Залежно від часу шпиталізації (по роках) хворих поділили на дві групи: контрольна група (2006-2012 pр.) - 117 (53,67\%) осіб; досліджувана група (2013-2019 рр.) 101 (46,33\%) пацієнт. Причинами поділу на групи $€$ використання в досліджуваній групі новітніх інноваційних технологій для діагностики: комп'ютерна томографія (КТ), магнітно-резонансна томографія (МРТ), ультразвукове дослідження (УЗД) + кольо- 
Оригінальні дослідження. Абдомінальна хірургія

Таблиця 1

Нозологічна характеристика хворих на інтраабдомінальні ускладнення по групах дослідження

\begin{tabular}{|c|c|c|c|c|c|c|c|c|c|c|c|c|c|c|c|c|c|}
\hline \multicolumn{18}{|c|}{ У 218 хворих хвороба ускладнилася інфільтратом і абсцесом } \\
\hline \multicolumn{12}{|c|}{ Первинні інтраабдомінальні ускладнення } & \multicolumn{6}{|c|}{ Вторинні } \\
\hline \multicolumn{4}{|c|}{ ДА } & \multicolumn{4}{|c|}{$\Pi B$} & \multicolumn{4}{|c|}{ Дх } & \multicolumn{6}{|c|}{ уло } \\
\hline \multicolumn{18}{|c|}{ Відсотки (\%) у цілому від загальної кількості 218 хворих } \\
\hline \multicolumn{4}{|c|}{$\begin{array}{c}74(33,95 \%) \\
4-38, \%-36\end{array}$} & \multicolumn{4}{|c|}{$\begin{array}{c}48(22,02 \%) \\
4-37, *-11\end{array}$} & \multicolumn{4}{|c|}{$\begin{array}{c}69(31,65 \%) \\
4-21, \Psi-48\end{array}$} & \multicolumn{6}{|c|}{$\begin{array}{c}27(12,38 \%) \\
4-11, \nVdash-16\end{array}$} \\
\hline \multicolumn{18}{|c|}{ Відсотки (\%) у кожній групі, індивідуально за 100,0\% } \\
\hline \multicolumn{4}{|c|}{ ДА 74 (100,0\%) } & \multicolumn{4}{|c|}{$\Pi B-48(100,0 \%)$} & \multicolumn{4}{|c|}{ ДХ- $69(100,0 \%)$} & \multicolumn{6}{|c|}{ УЛО - $27(100,0 \%)$} \\
\hline \multicolumn{2}{|c|}{$\begin{array}{c}\mathrm{K} \Gamma- \\
39(52,70 \%) \\
\end{array}$} & \multicolumn{2}{|c|}{$\begin{array}{c}\text { ДГ- } \\
35(47,30 \%) \\
\end{array}$} & \multicolumn{2}{|c|}{$\begin{array}{c}\mathrm{K} \Gamma- \\
26(54,17 \%) \\
\end{array}$} & \multicolumn{2}{|c|}{$\begin{array}{c}\text { ДГ- } \\
22(45,83 \%) \\
\end{array}$} & \multicolumn{2}{|c|}{$\begin{array}{c}\mathrm{K} \Gamma- \\
37(53,62 \%) \\
\end{array}$} & \multicolumn{2}{|c|}{$\begin{array}{c}\text { ДГ- } \\
32(46,38 \%) \\
\end{array}$} & \multicolumn{3}{|c|}{ КГ- $15(55,55 \%)$} & \multicolumn{3}{|c|}{ ДГ- $12(44,45 \%)$} \\
\hline A & 1 & A & 1 & A & I & A & 1 & A & $\mathrm{I}$ & A & $\mathrm{I}$ & A & Py & 1 & A & Py & 1 \\
\hline 32 & 7 & 16 & 19 & 8 & 18 & 20 & 2 & 35 & 2 & 24 & 8 & 3 & 8 & 4 & - & 8 & 4 \\
\hline \multicolumn{18}{|c|}{ Повторні операції з причини післяопераційних інтраабдомінальних ускладнень } \\
\hline 4 & 3 & 2 & 1 & 3 & 1 & 1 & 1 & 4 & 2 & 2 & 1 & 3 & 8 & 4 & - & 8 & 4 \\
\hline
\end{tabular}

Примітки: ДА - деструктивний апендицит, ДХ - деструктивний холецистит, ПВ - перфоративна виразка шлунка та дванадцятипалої кишки, УлО - ургентні лапаротомні операції (спайкова непрохідність та ускладнені грижі різної локалізації), Кг-контрольна група (за 2006-2012 рр.), Дг - досліджувана група (за 2013-2019рр.), А - абсцес, I - інфільтрат, РУ - рідинне утворення.

рове дуплексне картування + еластографія, термометрія), а також новітніх загальновизнаних та вдосконалених методик хірургічного лікування: лапароскопія та гідроструменеві технології розділення тканин. У подальшому всіх хворих контрольної і досліджуваної груп поділили на 4 підгрупи залежно від чинників захворювання. Поміж тим, усі 4 групи хворих - це особи, які шпиталізовані в ургентному порядку та мали оперативне лікування після дообстеження і передопераційної підготовки. Під час госпіталізації провели загальноклінічне і біохімічне обстеження крові та сечі у всіх хворих. Рентгенологічне дослідження (оглядову рентгенографію органів черевної порожнини у вертикальному та поліпозиційному положенні) провели 129 (59,19\%) хворим, КТ - 49 (22,48\%); УЗД органів черевної порожнини - 105 (48,16\%) хворим, а дослідження стану кровотоку утворення - кольорове дуплексне картування - 43 (19,72\%), еластографію 43 (19,72\%) особам. Ректальне і бімануальне дослідження виконали 127 (58,26\%) пацієнтам; термометрію передньої черевної стінки - 76 (34,86\%) хворим.

Дослідження виконали відповідно до принципів Гельсінської декларації. Протокол дослідження ухвалили Локальним етичним комітетом зазначених установ. На проведення досліджень отримали інформовану згоду пацієнтів.

\section{Результати дослідження та їх обговорення}

Для вирішення мети дослідження та залежно від розвитку недуги й проведення лікування хворих поділили на дві групи: первинні - доопераційні інфільтрати й абсцеси - у 191 (87,61\%) осіб; вторинні після- операційні інфільтрати й абсцеси - у 27 (12,39\%) пацієнтів (це на початку відбору клінічного матеріалу). Причинами виникнення первинних інфільтративних й абсцедуючих утворень черевної порожнини були: ускладнені форми апендициту - у 74 (33,94\%), перфоративна виразка (ПВ) шлунка та дванадцятипалої кишки - у 48 (22,02\%), ускладнені форми холециститу - у 69 (31,65\%). До основних післяопераційних ускладнень у $27(12,39 \%)$ випадках, що слугували розвитку вторинних інфільтративних й абсцедуючих утворень, належали: адгеолізис після хірургічного лікування спайкової непрохідності у $14(6,42 \%)$, великих розмірів грижі різної локалізації з клінікою непрохідності кишечника на тлі защемлення - у 13 (5,97\%). Поміж тим, із 191 (87,61\%) хворого з первинними ускладненнями в післяопераційному періоді встановили післяопераційні ускладнення у 25 (13,08\%). Таким чином, післяопераційні ускладнення внаслідок видалення деструктивного та ускладненого апендициту виявили у $10(13,51 \%)$ із 74 осіб, ПВ шлунка та дванадцятипалої кишки - у $6(12,5 \%)$ з 48 , деструктивного ускладненого холециститу - у 9 (13,04\%) з 69 хворих. Поділ хворих по нозологічних групах дослідження і підгрупах наведено в таблиці 1.3 урахуванням стадійності перебігу післяопераційного періоду, поміж розвитком інфільтратів й абсцесів, групу з рідинними утвореннями виділили у 18 хворих, які потребували індивідуального вибору хірургічної тактики від пункційного методу до релапароскопії або релапаротомії. Як видно з таблиці, групи дослідження за кількістю пацієнтів були тотожними, що дало змогу проводити порівняння. 


\section{Анамнестичні дані}

Дослідження ретроспективного архівного матеріалу та поточного вивчення скарг і анамнезу перебігу поточної хвороби дало змогу встановити захворювання інших органів і систем, а також тривалість перебігу супутніх захворювань. Під час огляду пацієнта в приймальному відділенні, окрім скарг щодо основної хвороби, визначали масу тіла хворого, що $€$ стандартом при госпіталізації хворих. 3 метою дослідження ваги використовували індекс маси тіла (IMT). Результати дослідження показали таке: у 87 (39,91\%) хворих маса тіла була в межах норми, у

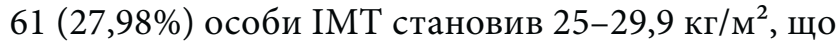
вказувало на передожиріння, при якому виражені симптоми ожиріння були відсутніми. Поміж тим, у $42(19,27 \%)$ пацієнтів IMT був у межах $30-34,9$ кг $/ \mathrm{m}^{2}$, що вказувало на І ступінь ожиріння, у 20 (9,17\%) хворих - у межах 35-39,9 кг/м² ступінь ожиріння, у 8 (3,67\%) осіб - понад 40 кг $/ \mathrm{m}^{2}$, що вказувало на III ступінь ожиріння. Таким чином, у $148(67,89 \%)$ осіб показники IMT не вказували на ожиріння, а в $70(32,11 \%)$ пацієнтів було порушення ваги різного ступеня. Наступним, на що звернули увагу в приймальному відділенні, було те, що $126(57,80 \%)$ хворих носили окуляри. Такі дані свідчили про порушення зору, з яких 32 (14,68\%) хворі носили окуляри з підліткового віку. Операції з приводу катаракти перенесли 26 (11,93\%) пацієнтів. Хвороби серцево-судинної системи та порушення тиску, за даними історій хвороб та анамнезу, мали $123(56,42 \%)$ хворі, із них інфаркт міокарда 32 (14,68\%), стентування перенесли 27 (12,38\%) осіб, ішемічну хвороба серця - 49 (22,48\%) пацієнтів. Цукровий діабет (ЦД) встановили у 38 (17,43\%) паці$\epsilon$ тів, які мали показники цукру крові понад 15 ммоль/л. Захворювання опорно-рухового апарату виявили у $27(12,38 \%)$ хворих, із них $4(1,83 \%)$ особи перенесли протезування кульшових суглобів. Дослідженнями встановлено, що 48 (22,02\%) хворих страждали від плоскостопості різного ступеня.

Усі хворі мали різного ступеня абдомінальний больовий синдром, який різнився локалізацією, іррадіацією залежно від вказаного захворювання. На рисунку 1 схематично наведено локалізацію абдомінального болю: a - при ДА, 6 - при ПВ шлунка, в при ДХ.

Фізикальне обстеження передньої черевної стінки провели у всіх хворих. 3більшення живота в розмірах за рахунок жирової клітковини встановили у $53(24,31 \%)$, помірне та рівномірне здуття живота - у 72 (33,03\%), виражене здуття - у 47 (21,56\%), а асиметричний живіт - $46(21,10 \%)$ хворих. Рубці на пе- редній черевній стінці встановили у 39 (17,89\%) пацієнтів. Судинний малюнок був вираженим у 63 (28,90\%) хворих. Пальпація живота поверхнева була болючою у всіх хворих, а глибока пальпація мала свої особливості, детальніше описані в кожній підгрупі. Термометрію передньої черевної стінки виміряли 76 (34,86\%) хворим досліджуваної групи.

Клініко-лабораторне дослідження передбачало загальний аналіз крові та його біохімічне дослідження, а також загальний аналіз сечі. Досліджували показники червоної та білої крові (лейкоцити (L) і паличкоядерні (п/я) клітини). У групах наведено результати лабораторного дослідження та їх зміни залежно від ступеня запального процесу в черевній порожнині.

Діагностика ускладненого перебігу апендициту в контрольній групі хворих грунтувалася на даних анамнезу, клініко-лабораторних і даних пальпації.

У контрольній групі хворих основними візуалізаційними методами обстеження пацієнтів була оглядова рентгенографія черевної та грудної порожнини, яку виконали хворим із клінікою ПВ шлунка та дванадцятипалої кишки, а також хворим із підозрою на непрохідність кишечника на тлі запального процесу. УЗД черевної порожнини в цій групі провели 12 хворим. Це був початок впровадження методу в ургентній хірургіï. Аналіз ретроспективних даних у 26 (13,61\%) хворих на ПВ шлунка та дванадцятипалої кишки показав, що у $6(23,07 \%)$ із 26 не встановили вільного повітря в черевній порожнині, а тільки за результатами фіброгастродуоденоскопії (ФЕГДС) виявили перфорацію та вільне повітря в черевній порожнині, що підтвердили повторним дослідженням. Рентгенологічне дослідження провели у $14(18,42 \%)$ з 76 хворих, які мали клініку непрохідності кишечника, на тлі запального процесу, причиною якого був деструктивний апендицит - ДА (у $5(12,82 \%)$ з 39 осіб) та деструктивний холецистит - ДХ (у 9 (24,32\%) з 37 пацієнтів). Таким чином, у контрольній групі хворих основним постулатом, на якому грунтувався діагноз, був власне досвід хірурга за результатами анамнезу та клінічного і лабораторного обстеження, що в подальшому підтвердили інтраопераційно.

У досліджуваній групі хворих у приймальному відділенні проаналізували анамнез, а під час огляду виміряли нашкірну температуру передньої черевної стінки у $48(53,93 \%)$ з 89 хворих, з них у $39(81,25 \%)$ 348 вона була підвищеною на $2-3^{\circ} \mathrm{C}(32(91,42 \%) 3$ 35 хворих на ДА, $7(21,87 \%)$ із 32 хворих на ДХ), а у $9(18,75 \%)$ з 48 з причини збільшеного живота та вираженого жирового шару (складки жирового шару) 

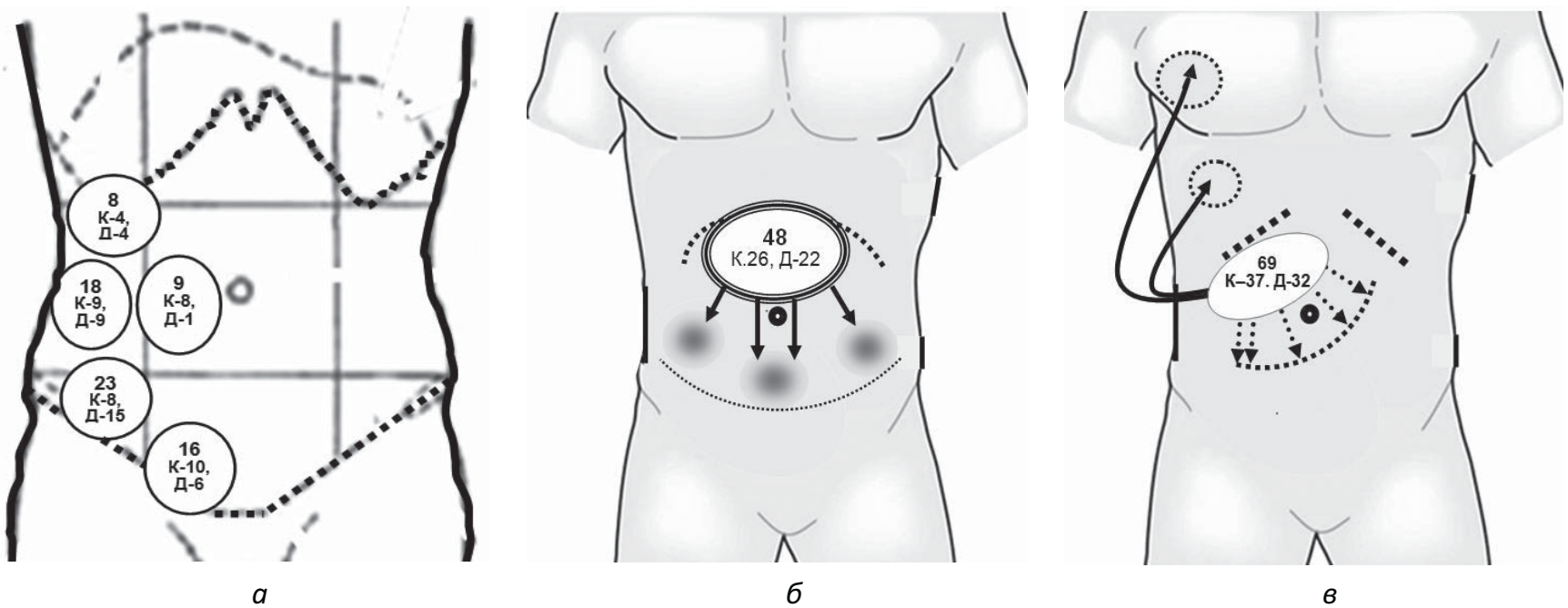

Рис. Локалізація больового синдрому: а - при деструктивному апендициті, б - перфоративній виразці шлунка, в - деструктивному холециститі

метод не був інформативним. У подальшому на основі маршруту пацієнта провели дослідження крові та сечі, рентгенологічне та УЗД. У результаті УЗД черевної порожнини встановили як прямі, так і непрямі ознаки запального процесу в черевній порожнині та його наслідки. Поміж тим, інформативність візуалізації залежала від кількості повітря в просвіті кишечника. УЗД провели $81(91,01 \%)$ хворому із 89 пацієнтів, з яких при ДА - 35 (100\%) із 35, при ДХ - $32(100 \%)$ із 32, при ПВ - $14(63,63 \%)$ із 22. Результати дослідження при ДА показали, що ДА встановлено у 68 із 72, з яких апендикулярний абсцес - у 15 (93,75\%) із 16, а апендикулярний інфільтрат - у $18(94,73 \%)$ із 19 , а також різний ступінь регіонарного мезаденіту та вмісту рідини в черевній порожнині. За даними візуалізації як ДА, так і апендикулярних абсцесів й інфільтратів встановили локалізацію (розташування) апендикулярного паростка, з яких типову локалізацію - у $22(62,85 \%)$ iз 35 , медіальне - у $6(17,14 \%)$ із 35 , підпечінкове у $7(20,0 \%)$ iз 35 . Виявили непрямі ознаки УЗД при ДА: вільна рідина як по правому фланку у $32(91,42 \%)$ iз 35 із включеннями, а також у ділянці кореня брижі кишечника - у $8(22,85 \%)$ iз 35 , набряк стінки тонкого кишечника - у 29 (82,85\%) iз 35, порушення (зменшення) перистальтики кишечника - у $28(80,0 \%)$ із 35, локальна прискорена перистальтика - у $3(8,57 \%)$ із 35, збільшення та набряк брижових й ілеоцекальних лімфатичних вузлів у всіх 35 хворих. Допплерографічне дослідження показало збільшення кровотоку в інфільтративних тканинах великого чіпця та стінках кишки у $19(54,28 \%)$ iз 35 хворих. Натомість, за наявності абсцесу в центрі візуалізували рідинне утворення
3 відсутністю кровотоку. УЗД жовчного міхура провели $32(100 \%)$ пацієнтам із 32 хворих досліджуваної групи. За результатами УЗД встановили: наявність конкрементів у просвіті - у $12(37,5 \%)$ iз 32 , набряк стінки жовчного міхура понад 5 мм у $30(93,75 \%)$ із 32 , наявність газу у стінці у $21(65,62 \%)$ iз 32, позитивний ультрасонографічний симптом Мерфі - у всіх пацієнтів, збільшення розмірів жовчного міхура - у $31(96,87 \%)$ із 32, зміни у просвіті жовчного міхура (осад) - у $15(46,87 \%)$ із 32 , скупчення рідини навколо жовчного міхура у $24(75,0 \%)$ із 32 та інфільтративний перивезикальний процес - у $8(25,0 \%)$ із 32 . Кольорове дуплексне картування провели 13 (40,62\%) хворим із 32 пацієнтів і встановили порушення кровообігу в стінці жовчного міхура - від зменшення ділянками до повної відсутності кровообігу (ділянки деструкції), а також посилення кровообігу у великому чіпці, який обгортав жовчний міхур із перивезикальною рідиною та був інфільтративно зміненим. УЗД провели $11(50,0 \%)$ особам із 22 хворих на ПВ, яке було інформативними у $5(22,72 \%)$ iз 22 із візуалізацією вільної рідини в порожнині малого тазу та по фланках, але у $6(27,27 \%)$ iз 22 пацієнтів із причини великої кількості повітря не вдалося візуалізувати чіткі межі інфільтративного утворення.

Рентгенологічне дослідження органів черевної порожнини хворих на ДА провели з причини підозри на непрохідність кишечника (вертикальна позиція) у $10(28,57 \%)$ із 35 та встановили парез кишечника на тлі запального процесу і прояви рідини в просвіті тонкого кишечника у $8(80,0 \%)$ із 10 пацієнтів. Оглядову рентгенографію виконали 5 (15,62\%) особам із 32 хворих, що страждали від ДХ, з яких 
у всіх 5 хворих візуалізували конкременти. Оглядову рентгенографію виконали 22 хворим, що страждали від ПВ шлунка та дванадцятипалої кишки, з яких вільне повітря різної кількості під куполами діафрагми встановили у $17(77,27 \%)$ із 22 хворих. 3 метою верифікації захворювання та прискіпливої візуалізації патологічного процесу в черевній порожнині провели КТ 16 хворим, із яких 5 особам із ПВ з причини неінформативності (відсутності повітря) оглядової рентгенографії, та 11 - з метою диференційної діагностики візуалізації підпечінкового ДА. За даними КТ візуалізували ПВ препілоричного відділу, а також підпечінкове розташування ДА. Отримані результати клініко-лабораторного та інструментального обстеження в досліджуваній групі доповнили відповідно підгрупи архівними даними в контрольній групі.

До першої групи з ускладненими формами ДА увійшли $74(100,0 \%)$ хворі з первинними пухкими інфільтратами й абсцесами апендикулярного походження: у контрольній групі - 39 (17,88\%) пацієнтів, досліджуваній - 35 (16,06\%) осіб. Скарги хворих на виражений абдомінальний біль висловлювали всі хворі, із яких на нестерпний - $26(35,14 \%)$ осіб, пульсуючий - $48(64,86 \%)$ пацієнтів. Усі хворі приймали вимушене положення на правому боці, яке сприяло полегшенню стану. Порушення апетиту мали всі хворі, з яких нудоту мали $16(21,62 \%)$ осіб, одноразове блювання - $32(43,24 \%)$ пацієнти, багаторазове - $26(35,14 \%)$ хворих. Порушення частоти та глибини дихання виявили у 58 (78,38\%) хворих. Загальна температура мала фебрильний характер у всіх хворих, із яких в $11(14,86 \%)$ пацієнтів $\mathrm{t}=37,5 \pm 0,76^{\circ} \mathrm{C}$, y $15(20,27 \%)$ oci $\mathrm{t}=38,7 \pm 0,52^{\circ} \mathrm{C}$, у $48(64,97 \%)$ хворих $\mathrm{t}=39,5 \pm 0,41^{\circ} \mathrm{C}$. Термометрію нашкірної температури передньої черевної стінки виконали безконтактним інфрачервоним термометром та порівняли 3 аксилярною у 30 (40,54\%) хворих, що дало змогу констатувати локальне підвищення температури (локалізації розташування апендикса) на $2,05 \pm 0,11^{\circ} \mathrm{C}$ порівняно $з$ іншими зонами передньої черевної стінки та аксилярною температурою. Пальпація черевної порожнини дозволила встановити інфільтративні утворення в 5 зонах розмірами $12,52 \pm 2,34$ см на $15,12 \pm 1,89$ см із локально вираженою болючістю в центрі у $48(64,86 \%)$ та менш вираженим болем, але більшою щільністю у 26 (35,14\%) осіб, що схематично наведено на рисунку. Симптоми подразнення очеревини (перитоніальні симптоми) були позитивними у всіх хворих. Подальшими дослідженнями встановлено, що зміна інтенсивності болю пов'язана з утвореним абсцесом і м’яким інфільтратом. Під час УЗД органів черевної порожнини виявили як основні ознаки інфільтрату у $26(35,14 \%)$ чи абсцесу у $48(64,86 \%)$ хворих, а також характер і поширення інфільтративного процесу. В досліджуваній групі провели: УЗД + кольорове дуплексне картування $12(16,22 \%)$ особам, а компресійну та зсувну еластографію - 21 (28,38\%) пацієнтові. Рентгенологічне дослідження органів черевної порожнини з причини підозри на непрохідність кишечника (вертикальна позиція) виконали $23(31,08 \%)$ особам, з яких у контрольній групі 15 (20,27\%), досліджуваній групі - 8 (10,81\%). Парез кишечника на тлі запального процесу мав прояв рівнів рідини у просвіті тонкого кишечника у 18 (24,32\%) хворих. Ректальне дослідження було інформативним у $57(91,93 \%)$ із 62, із яких у контрольній групі - у 28 (37,84\%), у досліджуваній у $34(45,94 \%)$ хворих. у загальному аналізі крові показники червоної крові у $62(83,78 \%)$ мали такі дані: $\mathrm{Hb}=97 \pm 3,14$ г/л, $\mathrm{Er}=2,8 \pm 0,75 \times 10^{12}$, а у $12(16,22 \%)$ пацієнтів: $\mathrm{Hb}=86 \pm 2,12$ г/л, $\mathrm{Er}=2,6 \pm 1,14 \times 10^{12}$. Зміни лейкоцитів різнилися залежно від тривалості й гостроти гнійно-запального процесу. Так, у $36(48,64 \%)$ хворих $\mathrm{L}=18,5 \pm 2,11 \times 10^{9}$, у $26(35,14 \%)$ осіб $\mathrm{L}=21,2 \pm 2,23 \times 10^{9}$, у $12(16,22 \%)$ пацієнтів $\mathrm{L}=32,2 \pm 3,24 \times 10^{9}$, зі збільшенням сегментоядерних лейкоцитів відповідно від $68 \pm 1,21 \%$ до $79 \pm 1,11 \%$, а також нейтрофілів (паличкоядерних) від $25 \pm 2,51 \%$ до $38 \pm 2,13 \%$. Хірургічне лікування хворих з ДА різнилося по групах. Так, хірургічний доступ у $42(56,76 \%)$ хворих був лапаротомний i пов'язаний з локалізацією інфільтративно абсцедуючого утворення, з яких в $11(14,86 \%)$ - серединна лапаротомія, у 31 (41,89\%) - правобічна трансректальна. Лапароскопічний метод застосували у $32(43,24 \%)$ хворих, з яких у $12(16,22 \%)$ осіб у зв'язку з технічними труднощами провели конверсію. Причинами конверсії були: початок впровадження лапароскопічних технологій - у 4 (5,40\%) хворих, а також нетипове розташування інфільтративно-абсдедуючого утворення: підпечінкове у 2 (2,70\%), заочеревинне - у 5 (6,76\%), у порожнині малого таза - в 1 (1,35\%). Розділення інфільтративного утворення провели у контрольній групі механічним шляхом із застосуванням монополярної коагуляції та прошивання тканин 39 (52,70\%) особам, а у досліджуваній групі - за допомогою гідроструменевого скальпеля 15 (20,27\%) хворим. у досліджуваній групі застосували апарат «LigaSureTM» у $35(47,30 \%)$ хворих, з яких у $15(20,27 \%)$ - під час лапаротомії, у 20 (27,03\%) - під час лапароскопії. Брижу апендикса виділили та наклали шви, з яких 


\section{Оригінальні дослідження. Абдомінальна хірургія}

у 39 (52,70\%) - один шов, у 25 (33,78\%) - два шви, а у 35 (47,30\%) осіб брижейки апендикса і судини обробили біполярною коагуляцією. Куксу перев'язаного апендикса погрузили під кисетний i $\mathrm{Z}$-подібний шов у 38 (51,35\%), а у 16 (21,62\%) осіб через виражений запальний процес на куполі наклали окремі шви в кількості від 6 до 8. Під час лапароскопії, яку провели 20 (27,03\%) хворим, на основу паростка наклали механічний і Z-подібний шов 5 (6,76\%) пацієнтам. Санацію черевної порожнини провели всім хворим до повного видалення гнійного вмісту і фібрину. Дренування черевної порожнини виконали всім хворим через окремий доступ, з яких до зони розташування інфільтративно-абсцедуючого утворення - у 47 (63,51\%) і порожнини тазу - у 46 (62,16\%) хворих. у післяопераційному періоді встановили ускладнення з боку черевної порожнини у 10 (13,51\%) осіб і післяопераційної рани у 25 (33,78\%) хворих. Ускладнення післяопераційної рани мали такий характер: інфільтрат у $14(18,92 \%)$, сірому післяопераційної рани у $9(12,16 \%)$, нагноєння рани - у 3 (4,05\%) осіб (контрольної групи). Повторні операції були виконані 7 особам із 39 хворих контрольної групи, які перенесли першу операцію з причини ускладненого ДА. у таких осіб при релапаротомії встановили в черевній порожнині: кишковий вміст - у 2 (28,57\%) із 7 , гнійний вміст - у $2(28,57 \%)$ із 7, інфільтративне утворення - у $3(42,85 \%)$ із 7 . Під час детальної ревізії виявили неспроможність швів купола сліпої кишки після апендектомії у 2 (28,57\%) із 7, множинні міжпетльові абсцеси й абсцес правої здухвинної ділянки - у $2(28,57 \%)$ із 7, а інфільтративне утворення із залученням великого чіпця та петель кишечника у $3(42,85 \%)$ із 7. у $5(71,42 \%)$ із 7 пацієнтів прошиті нитки на великому чіпці були залучені до формування як абсцесу, так і інфільтрату. 5 хворим, які мали межпетльові абсцеси й інфільтративне утворення, провели сегментарну резекцію великого чіпця, санацію та дренування черевної порожнини. Поміж тим, 2 (40,0\%) особам із 5 хворих, що мали міжпетльові абсцеси, провели 3 програмовані санаційні релапаротомії. На тлі калового перитоніту 1 хворому наклали цекостому, ще 1 пацієнтові ілеостому. у подальшому провели від 3 до 6 програмованих санаційних релапаротомій. На тлі тромбозу мезентеріальних судин та етапних резекцій тонкої кишки один хворий із супутнім ЦД помер. Хворий з цекостомою одужав, за місяць йому виконали закриту цекостому. Повторні операції були виконані 3 особам із 35 хворих досліджуваної групи, які перенесли першу операцію з причини ускладне- ного ДА. у таких пацієнтів при релапаротомії встановили в черевній порожнині: кишковий вміст у $2(66,66 \%)$ із 3, інфільтративне утворення - в $1(33,33 \%)$ із 3 пацієнтів. Обсяг операції включав проведення санації з накладенням окремих швів на дефект у ділянці культі апендикулярного паростка та накладення кінцевої ілеостоми. у подальшому для санації цим хворим провели санаційну лапароскопію, а за 3 доби - повторну релапароскопію із санацією черевної порожнини. у цілому виконали від 3 до 5 релапароскопічних санацій. Незважаючи на поліантибактеріальну та інфузійну терапію на тлі поліорганної недостатності 1 пацієнт помер. у другого пацієнта запальний процес у черевній порожнині мав зворотний характер, за 3 тижні після виписки 3 клініки хворому наклали тонко-тонкокишковий анастомоз «кінець у кінець». у хворого з інфільтративним утворенням під час релапаротомії мобілізували інфільтративне утворення із залученням великого чіпця (за допомогою гідроструменевого скальпеля) і провели його сегментарну резекцію.

До другої групи увійшли 48 (100,0\%) осіб із ПВ шлунка та дванадцятипалої кишки. Стан цих хворих на момент госпіталізації був тяжким - третя стадія перебігу виразкової хвороби (стадія перитоніту). Скарги на абдомінальний біль висловлювали всі хворі, на початку захворювання біль носив «кинджальний» характер - стадія абдомінального шоку, але за 6-8 год біль почав зменшуватися та поширюватися. у дослідженні встановили передумови «кинджального» болю: нудота - у 28 (58,33\%), порушення харчового режиму та переїдання - у 24 (50,0\%), блювання від однократного до багаторазового у 31 (64,58\%). Поміж тим, у 21 (43,75\%) пацієнта виявили декілька передумов. Локалізація болю була виразнішою в епігастральній ділянці у 15 (31,25\%) хворих та в доповненні по фланках та малого тазу у 33 (68,75\%) осіб. Підвищення загальної температури в межах $38,4 \pm 0,65^{\circ} \mathrm{C}$ мали всі хворі, а локальна температура була підвищеною на $2,12 \pm 0,65^{\circ} \mathrm{C}$ від норми у $22(39,58 \%)$ пацієнтів досліджуваної групи. Положення хворого було вимушеним (напівсидячим) у 39 (81,25\%) осіб, а сидячим із піднятими до живота ногами - у 9 (18,75\%). Пальпаторно біль був найінтенсивнішим у верхніх відділах черевної порожнини у 36 (75,0\%) осіб та в доповнення по фланках - у $14(29,17 \%)$ хворих. Усі хворі мали симптоми подразнення очеревини, різного ступеня вираженості, а також різке напруження м'язів, позитивний симптом Щоткіна-Блюмберга, а перкуторно - відсутня печінкова тупість - над печінкою «тимпаніт». у загальному аналізі крові виявили показники чер- 
воної крові $\mathrm{Hb}=98 \pm 4,72$ г/л, $\mathrm{Er}=2,9 \pm 0,86 \times 10^{12}$, a $\mathrm{L}=16,5 \pm 2,31 \times 10^{9}$ зі збільшенням сегментоядерних до $78 \pm 1,28 \%$, а також нейтрофілів (палочкоядерних) до $36 \pm 2,56 \%$. у другій групі хірургічне лікування провели у $48(100,0 \%)$ хворих із ПВ шлунка і дванадцятипалої кишки, які мали інфільтративно запальний процес великого сальника. Під час вибору операційного доступу врахували тривалість захворювання понад 24 год, вік понад 60 років, а також супутні захворювання серцево-судинної системи (атеросклероз, кардіосклероз, стентування). Тому хірургічний доступ в усіх 48 хворих - серединна лапаротомія. Під час ревізії черевної порожнини визначили локалізацію перфорації (шлунок і дванадцятипала кишка), розміри та ії краї, а також поширеність інфільтративно-запального процесу як черевної порожнини, так і великого чіпця. Локалізація перфоративної виразки шлунка була: вище 5 см до цибулини дванадцятипалої кишки - у 7 (14,58\%), у середній третині ближче до малої кривизни у 12 (25,0\%), по великій кривизні на дні шлунка у $14(29,17 \%)$, у центрі шлунка - у $9(18,75 \%)$, на рівні цибулини дванадцятипалої кишки - у 10 (20,83\%), у передній частині дванадцятипалої кишки у 3 (6,25\%), у нижній частині дванадцятипалої кишки - у 5 (10,42\%) хворих. Під час ревізії виразки ії кальозні краї виявили у $18(37,5 \%)$ осіб, а кровоточивість - у $5(10,42 \%)$ хворих. Накладення швів на перфоративну виразку проводилося після відділення великого сальника від виразки та висічення країв рани від кальозно-склеротичного процесу. Усім хворим наклали дворядні шви з обов'язковим контролем герметичності накладених швів, 3 обов'язковою декомпресією шлунка і кишечника (один зонд - у шлунку, а другий - за зв'язкою Трейця для ентерального введення рідини). Мобілізацію великого чіпця в контрольній групі провели механічним шляхом, а в досліджуваній групі застосували гідроструменевий скальпель у 18 (37,5\%) хворих, а 3 метою гемостазу використали апарат «LigaSure ${ }^{\mathrm{TM}}$ » у $22(45,83 \%)$ пацієнтів. Для прикриття виразки застосували пасмо великого сальника у $36(75,0 \%)$ хворих. Після санації провели дренування черевної порожнини з окремого доступу. Під час дренування черевної порожнини в контрольній групі використали однопросвітні дренажі у $26(54,17 \%)$, а в досліджуваній - двопросвітні у $22(45,83 \%)$ хворих. Неспроможності швів на ПВ не встановлено. Видалення дренажів провели за відсутності виділень і за відновлення перистальтики на 4-6-ту добу післяопераційного періоду. Післяопераційні ускладнення діагностували в 11 (22,92\%) хворих, з яких інтраабдомінальні - у 6 (12,5\%), а з боку рани у $5(10,42 \%)$ пацієнтів. Інтраабдомінальні ускладнення мали клініку некупованого перитоніту в $6(12,5 \%)$, з яких релапаротомію виконали $4(8,34 \%)$ особам, а лапароскопію - $2(4,17 \%)$ пацієнтам. Усім хворим провели санацію черевної порожнини з продовженням дренування останньої. у 5 (10,42\%) хворих виявили такі ускладнення: інфільтрат післяопераційної рани - у 2 (4,17\%), сірому післяопераційної рани - у $3(6,25 \%)$ пацієнтів. Консервативні заходи мали ефективне лікування. Повторні, релапаротомні операції в контрольній групі були проведені $4(15,38 \%)$ особам із 26 хворих із причини ПВ шлунка та дванадцятипалої кишки, абсцеси великого чіпця встановлені у $3(75,0 \%)$ із 4. Інфільтрат, як великого чіпця, так і з залученням стінок кишечника, був в $1(25,0 \%)$ із 4 хворих на тлі серозного вмісту в черевній порожнині. Проведена сегментарна резекція великого чіпця в межах здорових тканин з абсцесами та інфільтративними утвореннями з подальшою санацією черевної порожнини. На третю добу після релапаротомії зменшився шлунковий стаз, а в подальшому відновилася перистальтика та видалені дренажі. Повторні операції - лапароскопічні в досліджуваній групі були проведені 2 особам із 22 хворих, із яких міжпетльові абсцеси (3) встановили в $1(50,0 \%)$ із 2 хворих, а інфільтративне утворення великого чіпця - в $1(50,0 \%)$ із 2 пацієнтів. Лапароскопічно видалили інфільтративне утворення. Через 3 дні виконали повторну санаційну релапароскопію 2 пацієнтам, а ще через 3 дні - 1 хворому з абсцесами. Черевна порожнина - без гнійно-запальних утворень. Усі хворі одужали та виписані з клініки.

До третьої групи увійшли 69 (100,0\%) хворих із гострим запаленням холециститу (з різними варіантами ускладнень). Усі хворі висловлювали скарги на сильний біль черевної стінки в ділянці правого підребер'я. Лихоманку з $\mathrm{t}$ до $38,4 \pm 0,53^{\circ} \mathrm{C}$ виявили у $57(82,61 \%)$ осіб, озноб з $\mathrm{t}=39,6 \pm 0,87^{\circ} \mathrm{C}$ у $12(17,39 \%)$ хворих. Блювання мали всі хворі, 3 яких нестерпне (постійне) - 45 (65,22\%), багаторазове - $16(23,19 \%)$, однократне з постійною нудотою - $8(11,59 \%)$ пацієнтів. Усі хворі мали тахікардію до Ps $=115 \pm 3,54$ на 1 хвилину та дихання ЧД=35 $\pm 2,27$ на 1 хвилину. При огляді живіт (верхні його відділи) не брав участі в диханні. При пальпації виявили біль у правому підребер'ї, з позитивними симптомами Мерфі та Ортнера. Лабораторні дослідження такі: лейкоцитоз зі зсувом лейкоцитарної формули вліво, L=14,5 $\pm 1,58 \times 10^{9}-$ у $32(46,38 \%)$ хворих, а $L=22,4 \pm 1,12 \times 10^{9}$ у $37(53,62 \%)$. Зсув формули вліво та 


\section{Оригінальні дослідження. Абдомінальна хірургія}

паличкоядерні $=14 \pm 1,12$ - у 34 (49,27\%), паличкоядерні=28 2,11 - у 35 (50,72\%). Підвищену концентрацію С-реактивного білка у сироватці крові до $15 \pm 1,29$ мг/л виявили у всіх хворих. Гіпербілірубінемію з показниками до 23,1 1,14 мкмоль/л у $47(68,12 \%)$, понад $31,2 \pm 1,21$ мкмоль/л у 22 (31,88\%). УЗД дослідження провели 30 (43,48\%) хворим досліджуваної групи. За результатами УЗД встановили: наявність конкрементів у $25(36,23 \%)$, набряк стінки жовчного міхура у 30 (43,48\%), наявність газу в стінці - у 21 (30,43\%), позитивний ультрасонографічний симптом Мерфi - у 30 (43,48\%), збільшення жовчного міхура у 30 (43,48\%), потовщення стінки жовчного міхура - у $30(43,48 \%)$, зміни у просвіті жовчного міхура - у 5 (7,25\%), скупчення рідини навколо жовчного міхура - у 24 (34,78\%), інфільтративний перивезикальний процес - у 6 (8,69\%). Враховуючи, що $16(23,19 \%)$ пацієнтів скаржилися і на больовий синдром у нижніх відділах живота з порушенням спорожнення, провели ректальне дослідження і виявили нависання передньої стінки у 5 (7,25\%) хворих. Таким чином, за результатами обстеження в контрольній групі з 37 (53,62\%) хворих абсцеси черевної порожнини відмітили у 35 (50,72\%), а інфільтрати - у 2 (2,90\%) пацієнтів. Хірургічне лікування виконали 69 (100\%) хворим, які страждали на ускладнений холецистит. Хірургічний доступ обгрунтували за результатами комплексного обстеження. Лапаротомію провели 43 (62,32\%) хворим, з яких 37 особам контрольної групи та 6 хворим досліджуваної, а лапароскопію - 26 (37,68\%) пацієнтам досліджуваної групи, з яких 5 (7,25\%) особам провели конверсію через виражений спайково-склеротичний процес у черевній порожнині. Під час ревізї як при лапаротомії, так і при лапароскопії встановили, що у всіх 69 хворих в організації інфільтративно-абсцедуючого утворення брав участь жовчний міхур, великий сальник, а у 18 (26,08\%) - і стінки товстої кишки. Розділення інфільтративного утворення провели механічним шляхом 37 (53,62\%) хворим контрольної групи, а в досліджуваній - в 11 (15,94\%) хворих використовували гідроструменевий скальпель і апарат «LigaSure ${ }^{\mathrm{TM}}$ ». Вторинні зміни у великому сальнику були показанням до резекції останнього від сегментарної до субтотальної, із застосуванням швів у контрольній групі, та біполярної коагуляції апаратом «LigaSure $\mathrm{TM}_{\Downarrow .}$ у повному обсязі лапароскопічну холецистектомію виконали 21 (30,43\%) особам із 32 хворих. Резекцію сальника різних за обсягом (крайова, сегментарна, субтотальная) провели
29 (42,03\%) пацієнтам. Усі операції закінчили дренуванням черевної порожнини. Післяопераційні ускладнення діагностували у 12 (17,39\%) пацієнтів, з яких інтраабдомінальні - у 9 (13,04\%), з боку рани - у 3 (4,35\%). Інтраабдомінальні ускладнення у 9 (13,04\%) хворих мали клініку не купованого перитоніту, у зв'язку з чим 4 (5,79\%) пацієнтам провели санаційну релапаротомію, а 5 (7,25\%) - санаційну лапароскопію. 33 (4,35\%) пацієнтів виявили нагноєння післяопераційної рани у 2 (2,90\%) хворих контрольної групи і в 1 (1,45\%) особи досліджуваної групи. Санацію гнійної рани досягли зняттям швів, купіруванням запального процесу і накладенням вторинних швів. Повторні операції в контрольній групі - релапаротомії провели $6(16,21 \%)$ особам із 37 хворих. Абсцеси великого чіпця виявили у $4(66,66 \%)$ із 6 пацієнтів, а інфільтративне утворення - у $2(33,34 \%)$ із 6 хворих на тлі серозного перитоніту. Під час ревізії встановили спроможність швів культі кукси жовчної протоки. Провели сегментарну резекцію великого чіпця, що мав як абсцедуючі утворення, так і інфільтративні зміни з подальшою санацією та дренуванням черевної порожнини. Відновлення перистальтики почалося з 4-ї доби після релапаротомії, а на 5-ту добу були видалені дренажі. Повторні операціі в досліджуваній групі провели лапароскопічно $3(9,37 \%)$ особам із 32 хворих, які перенесли операцію з причини ДХ, а дані ревізії показали наявність міжпетльових абсцесів у 2 (66,66\%) із 3 пацієнтів та інфільтративне утворення в $1(33,34 \%)$ із 3 пацієнтів. Лапароскопічно провели санацію міжпетльових абсцесів і видалили інфільтративне утворення великого чіпця. У подальшому хворим, які мали абсцеси, провели по 3 санаційні релапароскопії до повного призупинення запального процесу. Усі хворі одужали та виписані з клініки.

До четвертої групи увійшли 27 (100,0\%) хворих, які перенесли ургентні інтраабдомінальні операції 3 причини: непрохідності кишечника - 14 (51,85\%), ускладнених защемлених гриж різної локалізації 13 (48,15\%). у цій групі вторинні післяопераційні пухкі інфільтративні, абсцедуючі та рідинні утворення встановили у 15 (55,55\%) хворих контрольної групи і у 12 (44,45\%) осіб досліджуваної групи, а залежно від ускладнення: інфільтрати - у 6 (22,22\%), абсцеси - у $3(11,12 \%)$, рідинні утворення у 18 (66,66\%) осіб. у контрольній групі з 15 хворих встановили: інфільтрати - у 4 (14,81\%), абсцеси у $3(11,12 \%)$, рідинні утворення - у 8 (26,63\%). У досліджуваній групі з 12 хворих діагностували: інфільтрати - у $2(7,41 \%)$, рідинні утворення - 
у $10(37,04 \%)$. Дослідження хворих за статтю показало, що серед хворих було $11(40,74 \%)$ чоловіків і $16(59,26 \%)$ жінок, з яких у контрольній групі відповідно 4 (14,81\%) і 11 (40,74\%) хворих, а в досліджуваній - відповідно 7 (25,92\%) і 5 (18,53\%) пацієнтів. Залежності від віку і статі встановили такі дані: від 25 до 54 років - $8(29,63 \%)$ осіб, із них 3 (11,11\%) чоловіки і $5(18,52 \%)$ жінок; від 55 до 64 років - $9(33,33 \%)$ пацієнтів, із них $5(18,52 \%)$ чоловіків і 4 (14,81\%) жінки; від 65 років - $10(37,04 \%)$ хворих, з них $3(11,11 \%)$ чоловіки і $7(25,93 \%)$ жінок. Дослідженнями встановлено кількість госпіталізованих хворих залежно від місяця року та кварталу року: I квартал - 9 (33,33\%), II квартал - 5 (18,52\%), III квартал - 6 (22,22\%), IV квартал - 7 (25,93\%) осіб. у всіх хворих тривалість захворювання була понад 24 год. Клінічна картина була типовою для непрохідності кишечника: з ознаками странгуляційної спайкової непрохідності - у 14 (51,85\%), защемлені грижі різної локалізації - у 13 (48,15\%). 3 огляду на відсутність перитоніту при першій операції, дренування черевної порожнини не проводили. у післяопераційному періоді всі хворі лихоманили: до $38,0^{\circ} \mathrm{C}$ - у $16(59,26 \%)$ пацієнтів, а понад $38,1^{\circ} \mathrm{C}$ - в 11 (40,74\%) осіб. Післяопераційний моніторинг загального аналізу крові свідчив про прогресування інтраабдомінального запального процесу: лейкоцити $38,6 \pm 1,3 \times 10^{9}$ упродовж 3 діб збільшилися до $19,9 \pm 1,5 \times 10^{9}$ у $24(88,89 \%)$ хворих. Зсув формули вліво та паличкоядерні з $6 \pm 1,12$ (на 2-гу добу після операції) збільшилися до $23 \pm 2,38$ (на 4-ту) у 24 (88,89\%) хворих. Дисфагічні розлади мали всі хворі, незважаючи на декомпресію шлунка. Так, нудоту мали $3(11,11 \%)$ хворі, а блювання на 2-гу добу $6(22,22 \%)$, на 3-ю добу - 18 (66,67\%) хворих, з яких блювання нестримного характеру - $6(22,22 \%)$ пацієнтів. Живіт мав збільшений вигляд у 24 (88,89\%) хворих. Пальпаторно визначили болючість ділянки післяопераційної рани, а також від пупка до лона. Аускультативно не виявили перистальтики у $24(88,89 \%)$ хворих, а у $3(11,11 \%)$ була різко ослабленою. Ректальне дослідження було інформативним - встановили болючість і нависання у $14(51,85 \%)$ хворих. Таким чином, у всіх 27 хворих у післяопераційному періоді виявили інтраабдомінальні ускладнення: абсцедуючі інфільтрати у $8(29,63 \%)$ пацієнтів, абсцеси - у 19 (70,37\%) хворих. Повторні операції всім 15 (55,55\%) хворим контрольної групи були проведені шляхом релапаротомії. Під час ревізії черевної порожнини у 9 хворих контрольної групи, які перенесли операцію 3 причини спайкової непрохідності, виявили: перито- ніт (як гнійний, так і з домішками кишкового вмісту) та неспроможність швів анастомозу у $2(22,22 \%) 3$ 9, множинні тонкокишкові перфорації - у 2 (22,22\%) з 9 хворих, а міжпетльові абсцеси - у $2(22,22 \%)$ з 9. Інфільтративні утворення відмітили у $3(33,33 \%)$ з 9 пацієнтів із локалізацією в ділянках пошкодження серозної оболонки, а основним утворюючим складовим інфільтрату був великий чепець. Сегментарну резекцію тонкої кишки провели 4 (44,44\%) особам з 9 хворих та наклали ілеостому, а в подальшому виконали їм від $5(71,42 \%)$ до 7 програмованих санаційних лапаротомій. у $3(75,0 \%)$ із 4 хворих розвинувся тромбоз брижових судин з етапним реілеостомуванням і поліорганною недостатністю з летальним наслідком. Натомість, 1 (25,0\%) хворому з 4 пацієнтів після 2 санаційних програмованих релапаротомій через місяць виконали операцію закриття ілеостоми з накладенням прямого тонкокишкового анастомозу «кінець у кінець». Усім хворим на етапах оперативного лікування - релапаротомії провели сегментарну резекцію великого чіпця в межах здорових тканин, санацію і дренування черевної порожнини. За даними релапаротомії та ревізії черевної порожнини, 6 хворих контрольної групи перенесли попередню операцію ускладнених гриж із резекцією ділянки тонкої кишки та накладення прямого анастомозу, а при повторній ревізії встановлено неспроможність анастомозу з виходом крізь дефект кишкового вмісту, а як наслідок, каловий перитоніт та множинні міжпетльові абсцеси та інфільтративні утворення у хворих. Наявність калового перитоніту слугувала показанням до накладення ілеостомії всім хворим із подальшим проведенням програмованої санаційної релапаротомії від 4 до 6, а їх кількість визначали станом і вмістом черевної порожнини. Незважаючи на поліантибактеріальну терапію та проведення програмованих санаційних релапаротомій, у $4(66,66 \%)$ із 6 хворих розвинулася клініка тромбозу мезентеріальних судин, що потребувало етапного реілеостомування. На тлі поліорганної недостатності померли 4 пацієнти. А 2 (33,34\%) особам із 6 хворих, після купірування перитоніту шляхом програмованих санаційних релапаротомій та дренування черевної порожнини, через місяць наклали тонкотонкокишковий анастомоз «кінець у кінець», пацієнти одужали та виписані з клініки. Повторні операції в досліджуваній групі були проведені 12 (44,45\%) хворим, з яких після спайкової непрохідності - 10 (83,33\%) із 12, після операцій з причини гриж - $2(16,67 \%)$ із 12 . Після усунення спайкової непрохідності післяопераційними ускладненнями 


\section{Оригінальні дослідження. Абдомінальна хірургія}

були рідинні утвори у $6(60,0 \%)$ осіб із 10 хворих та інфільтративні утворення в $4(40,0 \%)$ пацієнтів із 10 хворих. Натомість, після ускладнених гриж ускладнення у вигляді рідинних утворів виявили у 2 пацієнтів. Основним методом інвазійного лікування був ендоскопічний метод - лапароскопія та релапароскопія. Лапароскопічну ревізію черевної порожнини провели всім 12 хворим досліджуваної групи. у 10 хворих, які перенесли спайкову непрохідність, під час лапарокопії виявили: перитоніт у $4(40,0 \%)$ на тлі неспроможності міжкишкового анастомозу, гнійний вміст значної кількості у 2 (20,0\%). Лапароскопічно у 4 (40,0\%) з 10 хворих діагностували інфільтративні утворення із залученням великого чіпця (видалили разом із інфільтратом). Поміж тим, неспроможність міжкишкового анастомозу слугувала показанням до конверсії та релапаротомії. Інтраопераційно 4 хворим провели сегментарну резекцію з ілеостомією на тлі тотального гнійного та калового перитоніту. у подальшому провели санаційні лапароскопії, а кількість визначили індивідуально - від 3 до 5. у $2(50,0 \%)$ із 4 хворих після санаційної релапароскопії зберігався серозний вміст у черевній порожнині, а тому їм провели пункцію під контролем УЗД - без ускладнень. Поміж тим, у 2 (50,0\%) із 4 пацієнтів на тлі поліантибактеріальної та інфузійної терапії розвинулася поліорганна недостатність, 2 (25,0\%) хворі померли. А 2 (50,0\%) особам iз 4 хворих після 5 санаційних релапароскопій, а також після відновного лікування через 4 тижні виконали закриту ілеостому шляхом накладення тонко-тонкокишкового анастомозу «кінець у кінець». у досліджуваній групі за даними лапароскопічної ревізії черевної порожнини, проведеної 2 хворим, які перенесли операцію з причини защемлених і ускладнених гриж, встановили: рідинне утворення - в 1 хворого, яке лапароскопічно сановане; кишковий вміст - в 1 хворого (провели конверсію та релапаротомію). Причиною наявності кишкового вмісту був сегментарний некроз із множинними мікроперфораціями тонкої кишки, тому провели сегментарну резекцію, а на тлі гнійного перитоніту наклали ілеостому. у подальшому провели 4 санаційні лапароскопії з метою припинення поширення гнійного вмісту. В 1 (50,0\%) із 2 хворих зберігався серозний вміст у черевній порожнині - провели пункцію під контролем УЗД без ускладнень. В 1 (50,0\%) із 2 хворих, незважаючи на комплексне лікування, виник тромбоз мезентеріальних судин із проведенням етапних операцій та летальним наслідком. у другого хворого, який мав ілеостому, останню закрили через місяць шляхом накладення анастомозу «кінець у кінець».

На завершення доцільно вказати, що до дослідження увійшли 218 хворих, які були як госпіталізовані, так і прооперовані за ургентними показаннями. у контрольній групі було 117 хворих, з яких 102 особи мали первинні інтраабдомінальні ускладнення, а 15 пацієнтів перенесли як спайкову непрохідність, так і ускладнені грижі. Серед 102 хворих із первинними інтраабдомінальними ускладненнями інфільтрати відмічалися у 27 осіб, а абсцеси у 75 хворих. у післяопераційному періоді у 102 хворих спостерігалися такі післяопераційні ускладнення: інтраабдомінальні - у 17 (абсцеси - в 11, інфільтрати - у 6), а ускладнення з боку ранового каналу - у 23. Ускладнення з боку ранового каналу відмічалися при ДА у 18 осіб (3 - нагноєння післяопераційної рани, 9 - інфільтрати післяопераційної рани, 6 - серома післяопераційної рани), при ПВ у 3 (2 - нагноєння післяопераційної рани, 1 - серома післяопераційної рани), при ДХ - у 2 (2 - нагноєння післяопераційної рани) хворих. у контрольній групі після інтраабдомінальних операцій з причини спайкової непрохідності та ускладнених гриж післяопераційні ускладнення відмічалися у 15 хворих, із яких інфільтрати - у 4, рідинні утворення - у 8, абсцеси у 3. Таким чином, у цій групі серед 117 хворих релапаротомія (від 2 до 5) проводилася 32 пацієнтам, 3 яких неспроможність стінки кишки та кишкових швів відмічалася в 11 хворих, а повторна резекція тонкої кишки з накладенням ілеостоми проводилася 7 особам, а цекостоми - 1 хворому. Власне в контрольній групі померло 8 (6,84\%) хворих на тлі продовжуваного перитоніту, тромбозу мезентеріальних судин та поліорганної недостатності і супутніх захворювань.

Натомість, до досліджуваної групи увійшов 101 пацієнт, з яких 89 хворих мали первинні інтраабдомінальні ускладнення, а 12 осіб перенесли як спайкову непрохідність, так і ускладнені грижі. Основними хірургічними технологіями в лікуванні були ендовідеоскопічна (лапароскопія та релапароскопія), а при розділенні інтрабдомінального процесу - гідроструменевий скальпель. Поміж тим, ускладнення з боку післяопераційної рани відмічалися в 11 хворих, з яких при ДА - у 8 (5 - інфільтрат післяопераційної рани, 3 - серома пяляопераційної рани), при ПВ - у 2 (2 - інфільтрат післяопераційної рани), при ДХ - в 1 (1 - нагноєння післяопераційної рани). Інтраабдомінальні ускладнення спостерігалися у 20 пацієнтів, з яких абсцеси - у 5, інфільтрати - у 5, а рідинні утворення - у 10 хворих. Лапарос- 
копічно встановлено, що абсцеси й інфільтрати великого чіпця були у 9 з 16 хворих, а неспроможність стінки кишки і кишкових швів - у 7 пацієнтів. Резекція тонкої кишки з накладенням ілеостоми проводилася у 7 хворих. Померло 4 (3,96\%) хворих на тлі продовжуваного перитоніту, тромбозу мезентеріальних судин і поліорганної недостатності.

\section{Обговорення}

Обговорення проблеми доцільно почати з вітчизняних даних. Так, П.Д. Фомін і співавт. (2018) звернули увагу, що в Україні гостре запалення апендикулярного паростка становить 20,7 на 10 тис. населення, при цьому в частини хворих при пізньому зверненні розвивається перитоніт. Тим часом, летальність при ДА зумовлена такими чинниками: тяжкістю захворювання - 19,7\%; пізньою госпіталізацією - 46,1\%; технічними помилками під час операції - 5,2\%; тактичними помилками - 6,8\%; дефектами післяопераційного лікування - 7,7\%; супутніми захворюваннями - 9,3\%; пізньою операцією - 5,2\%. Гострий холецистит становить 6,25 на 10 тис. населення з коливанням від 1,48 до 10,8 на 10 тис. населення в різних регіонах. у 94-96\% хворих причиною виникнення хвороби $є$ жовчнокам'яна хвороба. Післяопераційна летальність складає в середньому 0,81-0,94\%, а при пізній госпіталізації 46,3-46,5\%, а кількість госпіталізованих пізніше 24 год від початку захворювання - 12,3-51,7\%. Перфоративні гастродуоденальної виразки становлять 1,88 на 10 тис. населення 3 коливанням від 1,08 до 2,57 на 10 тис., а післяопераційна летальність $-3,44 \%$ $(0,64-5,64 \%)$. Кількість пізно госпіталізованих пацієнтів дорівнює 0-20\% (у середньому - 12,5\%) при післяопераційній летальності серед госпіталізованих пізніше 24 год від початку захворювання 13,73\% (у середньому - 0-33,3\%). Гостра непрохідність кишечника посідає п'яте місце за поширеністю і становить понад $5 \%$ серед гострих хірургічних захворювань черевної порожнини. Водночас, за летальністю в абсолютних цифрах ця патологія займає одне з перших місць серед усіх гострих захворювань органів черевної порожнини. Грижі передньої черевної стінки складають 3-4\% усього населення $(2,64$ (у середньому - 0,45-4,07) на 100 тис. населення), а у 3-27\% хворих розвиваються ускладнення, що потребують оперативного лікування $[7,10]$.

За даними Di Saverio і співавт. (2020), які, описуючи історію захворюваності на ДА, вказали, що рівень захворюваність на цю патологію неухильно знижується $з$ кінця 1940-х років ХХ століття. Так, у розвинених країнах ДА зустрічається від 5,7-
50 пацієнтів на 100 тис. жителів на рік, з піком у віці від 10 до 30 років. Встановлено також географічні відмінності: так, довічний ризик виникнення ДА становить 9\% у США, $8 \%$ - в Європі, $2 \%$ - в Африці. Більше того, існують відмінності в методах обстеження й лікування пацієнтів, пов'язані з доходом у державі. у роботі акцентовано, що частота перфорації ДА коливається від 16\% до 40\%, у молодших вікових групах - 40-57\%, а в пацієнтів віком від 50 років - 55-70\%. Летальність при неперфоративному апендициті становить менше $0,1 \%$, але ризик зростає до 0,6\% при гангренозному паростку. 3 іншого боку, автори зазначили, що перфорація апендициту має вищий рівень смертності приблизно на 5\% [3]. Olanrewaju Samuel Balogun і співавт. (2019) в дослідженні ДА серед дорослих вказали, що частота перфорації становить $28,5 \%$, а загальний рівень ускладнень - 43,1\%. Акцентовано увагу, що найчастішими ускладненнями $€$ інфекції ділянки хірургічного втручання - 18,6\%, розбіжність післяопераційної рани - 15,2\%, абсцес порожнини таза - 13,5\% [2]. На сьогодні відводиться значна роль діагностичній візуалізації апендициту: УЗД, КТ і МРТ, що є важливим моментом у діагностиці захворювання. Наведені післяопераційні ускладнення, такі як ранова інфекція, інтраабдомінальний абсцес і кишкова непрохідність, становлять до $11,1 \%[11,16]$.

У своїй роботі Varut Lohsiriwat і співавт. (2009) провели аналіз лікування перфорованої виразкової хвороби у 152 пацієнтів (середній віковий діапазон 15-88 років), з яких 78\% чоловіків. Найчастішою локалізацією перфорованої виразкової хвороби була препілорична ділянка (74\%). Під час операції найпоширенішою процедурою було застосування великого сальника для закриття виразки. Частота ускладнень становила $30 \%$, а рівень загальної летальності - 9\%. 3 метою прогнозування післяопераційних ускладнень і летальності використовувалася шкала Воеу (Американського товариства анестезіологів), яка порівняно з індексом перитоніту Мангейма (Mannheim Peritonitis Index) $є$ простим i точним предиктором [6].

В аналітичній роботі F. Ausania і співавт. (2015) вказують, що перфорація жовчного міхура - небезпечне для життя ускладнення гострого холециститу, зустрічається приблизно у $2-11 \%$ пацієнтів. Автори на основі вивчення карток 1033 хворих виявили у 137 пацієнтів перфорацію жовчного міхура, що становило $12,4 \%$. За результатами лікування показники захворюваності і смертності дорівнювали $57,7 \%$ і 9,5\% відповідно [1]. Stefan Jansen і співавт. (2018) порівняли результати лікування перфо- 
ративного і неперфоративного холециститу. Автори показали, що рівень захворюваності становить $24 \%$ проти 7\%, смертності - 8\% проти 1\%, показник конверсії - 22\% проти 4\%, тривалість операції - 131,3 $\pm 55,2$ хв проти $100,4 \pm 47,9$ хв, а також

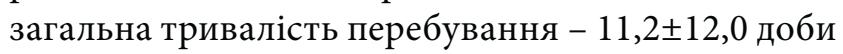
проти 5,8土6,5 доби (при перфоративному холециститі значно довше порівняно з групою без перфорації) [5].

В.В. Скиба і співавт. (2017), з метою розділення інфільтративно-запального та абсцедуючого утворення, застосували гідроструменевий скальпель, який дав змогу провести операцію без пошкодження серозної оболонки - безкровно $[14,15]$. Проте як КТ, так і СКТ є дороговартісними (але точними в більшості пацієнтів) методами обстеження, що потребує певного часу для проведення, а також наявності апаратів. А тому В.Ф. Рибальченко, Ю.Г. Демиденко $(2018,2019,2020)$ розробили, запатентували та запровадили в обстеженні хворих на інтраабдомінальні інфільтрати і абсцеси вимірювання температури передньої черевної стінки у всіх квадратах інфрачервоним термометром. у подальшому автори розробили «Термометричну панель передньої черевної стінки і прогностичний аксилярно-абдомінальний коефіцієнт» та отримали патент. Власне метод $€$ інформативним та ефективним як у діагностиці інтраабдомінальних гнійних захворювань, так і в прогнозуванні післяопераційного перебігу захворювання (щоденне вимірювання температури у всіх ділянках), при цьому не потребує фінансових вкладень і може проводитися в приймальному відділенні черговим хірургом $[11,12]$.

S. Massimo і співавт. (2017) провели багатоцентрове дослідження в 132 установах по всьому світу протягом 4-місячного періоду (жовтень 2014 року - лютий 2015 року). Дослідження охоплювало 4553 пацієнтів, які мали внутрішньочеревну інфекцію і отримували антибактеріальну терапію. За результатами дослідження, загальний рівень летальності становив 9,2\% [13].

На завершення слід акцентувати, що, незважаючи на певні досягнення, проблема вчасної діагностики, грунтовного обстеження і хірургічного лікування залишається не вирішеною з соціально-економічних причин.

\section{Висновки}

Обстеження 218 хворих показали, що первинні інтраабдомінальні інфільтрати й абсцеси встановлені: при ДА - у 74 (33,94\%) хворих, при ДХ у 69 (31,65\%) пацієнтів, при ПВ шлунка та дванадця- типалої кишки - у 48 (22,02\%) осіб, а вторинні післяопераційні - у 27 (12,39\%) пацієнтів, які перенесли ургентні операції на черевній порожнині (спайкова непрохідність, защемлені і післяопераційні грижі та інші), та у 29 (15,18\%) з 191 хворого, які перенесли операції з приводу первинних інтраабдомінальних ускладнень основного захворювання та ургентної операції.

Післяопераційні ускладнення діагностовані у 43 (19,72\%) хворих, з яких із боку операційної рани - у $34(15,59 \%)$, черевної порожнини у $29(15,18 \%)$ пацієнтів, які потребували проведення релапаротомії чи лапароскопії: при ДА - у 13,51\%, при ПВ шлунка та дванадцятипалої кишки - у 12,5\%, при ДХ - у 13,04\%, при спайковій кишковій непрохідності - у 18,57\%, при защемлених і ускладнених грижах - у 17,72\% обстежених хворих.

Хірургічне лікування $є$ індивідуальним залежно від захворювання. Так, при ДА з 74 (38,74\%) пацієнтів лапаротомія проведена 42 (21,99\%) хворим, лапароскопія - 32 (16,75\%) особам, а 12 (6,28\%) пацієнтам - із конверсією; при ПВ шлунка та дванадцятипалої кишки виконана відкрита лапаротомія $48(25,13 \%)$ особам; при холециститі $369(36,13 \%)$ хворих лапаротомія проведена $48(25,13 \%)$ особам, а лапароскопія - 21 (11,00\%) пацієнтові.

Застосування новітніх візуалізаційних і лікувальних технологій (допплерографії, гідроструменевого скальпеля та лапароскопії) у 64 (33,51\%) дало змогу отримати кращі близькі і віддалені результати з урахуванням якості життя та знизити рівень післяопераційної летальності з 6,84\% до 3,96\% при середньому показнику 5,5\%.

Автори заявляють про відсутність конфлікту інтересів.

\section{References/Лiтература}

1. Ausania F, Guzman Suarez S, Alvarez Garcia H, Senra del Rio P, Casal Nuñez E. (2015, Apr). Gallbladder perforation: morbidity, mortality and preoperative risk prediction. Surg Endosc. 29 (4): 955-960. doi: 10.1007/s00464-014-3765-6. Epub 2014 Aug 27.

2. Balogun Olanrewaju Samuel, Osinowo Adedapo, Afolayan Michael, Olajide Thomas, Lawal Abdulrazzak, Adesanya Adedoyin. (2019, Jan-Mar). Acute Perforated Appendicitis in Adults: Management and Complications in Lagos, Nigeria. Ann Afr Med. 18 (1): 36-41. PMC6380116. doi: 10.4103/aam.aam_11_18.

3. Di Saverio et al. (2020). Diagnosis and treatment of acute appendicitis: 2020 update of the WSES Jerusalem guidelines. World Journal of Emergency Surgery. 15: 27. doi. org/10.1186/s13017020-00306-3.

4. Fomin PD, Usenko OIu, Bereznytskyi YaS. (2018). Nevidkladna khirurhiia orhaniv cherevnoi porozhnyny (standarty orhanizatsii ta profesiino oriientovani alhorytmy nadannia medychnoi dopomohy). K.: Biblioteka «Zdorovia Ukrainy»: 354. [Фомін ПД, Усенко ОЮ, Березницький ЯС. (2018). Невідкладна 
хірургія органів черевної порожнини (стандарти організації та професійно орієнтовані алгоритми надання медичної допомоги). К.: Бібліотека «Здоров’я України»: 354].

5. Jansen Stefan, Stodolski Maciej, Zirngibl Hubert, Gödde Daniel, Ambe Peter C. (2018, Feb 23). Advanced gallbladder inflammation is a risk factor for gallbladder perforation in patients with acute cholecystitis. World Journal of Emergency Surgery. 13: 9. doi: 10.1186/s13017-018-0169-2.

6. Lohsiriwat V, Prapasrivorakul S, Lohsiriwat D. (2009). Perforated Peptic Ulcer: Clinical Presentation, Surgical Outcomes, and the Accuracy of the Boey Scoring System in Predicting Postoperative Morbidity and Mortality. World J Surg. 33: 80-85. doi. org/10.1007/s00268-008-9796-1.

7. MOZ Ukrainy. (2016). Unifikovanyi klinichnyi protokol ekstrenoi, pervynnoi ta vtorynnoi (spetsializovanoi) medychnoi dopomohy. Hostryi apendytsyt. Kyiv: 75. [MO3 України. (2016). Уніфікований клінічний протокол екстреної, первинної та вторинної (спеціалізованої) медичної допомоги. Гострий апендицит. Київ: 75].

8. Rusak PS. (2006). Maloinvazyvni tekhnolohii v likuvanni abstsesiv cherevnoi porozhnyny u ditei. Khirurhiia dytiachoho viku. III; 4 (13): 23-25. [Русак ПС. (2006). Малоінвазивні технології в лікуванні абсцесів черевної порожнини у дітей. Хірургія дитячого віку. III; 4 (13): 23-25].

9. Rusak PS. (2013). Likuvannia abstsesiv cherevnoi porozhnyny iz zastosuvanniam laparoskopii. Khirurhiia Ukrainy. 3 (47): 71-76. [Русак ПС. (2013). Лікування абсцесів черевної порожнини із застосуванням лапароскопії. Хірургія України. 3 (47): 71-76].

10. Rusak PS. (2018). Minimally invasive technologies in the treatment of abdominal abscesses in children. Paediatric surgery. Ukraine. 3 (60): 61-65. [Русак ПС. (2018). Мініінвазивні технології у лікуванні абсцесів черевної порожнини у дітей. Хірургія дитячого віку. 3 (60): 61-65]. doi 10.15574/ PS.2018.60.61.

11. Rybalchenko VF, Demydekno YuH. (2019). Termometrychna panel perednoi cherevnoi stinky ta prohnostychnyi aksyliarnoabdominalnyi koefitsiient. Neonatolohiia, khirurhiia ta perynatalna medytsyna. 9; 3 (33): 86-94. [Рибальченко ВФ, Демидекно ЮГ. (2019). Термометрична панель передньої черевної стінки та прогностичний аксилярно-абдомінальний коефіцієнт. Неонатологія, хірургія та перинатальна медицина. 9; 3 (33): 86-94]. doi: 10.24061/2413-4260.IX.3.33.2019.5.

12. Rybalchenko VF, Demydenko YuH, Yarmak SIa. (2018). Termometrychna panel perednoi cherevnoi stinky u ditei $\mathrm{z}$ in- filtratamy, abstsesamy apendykuliarnoho pokhodzhennia ta prohnostychnyi aksyliarno-abdominalnyi koefitsiient. Paediatric surgery. Ukraine. The materials of conference. 2 (59): 96. [Рибальченко ВФ, Демиденко ЮГ, Ярмак СЯ. (2018). Термометрична панель передньої черевної стінки у дітей з інфільтратами, абсцесами апендикулярного походження та прогностичний аксилярно-абдомінальний коефіцієнт. Xiрургія дитячого віку. Матеріали з'їзду. 2 (59): 96].

13. Sartelli Massimo, Chichom-Mefire Alain, Catena Fausto. (2017). The management of intra-abdominal infections from a global perspective: 2017 WSES guidelines for management of intraabdominal infections. World Journal of Emergency Surgery. Article number 29. 12 (12): 36

14. Skyba VV, Rybalchenko VF, Ivanko OV, Zinchuk AG, Badakh VM, Bocharov VP. (2017). The surgical treatment of an abdominal cavity infiltrations among adolescents using jet hydro scalpel. Paediatric surgery. Ukraine. 1 (54): 32-38. [Скиба ВВ, Рибальченко ВФ, Іванько ОВ, Зінчук ОГ, Бадах ВМ, Бочаров ВП. (2017). Хірургічне лікування інфільтратів черевної порожнини у підлітків з використанням струменевого гідроскальпеля. Хірургія дитячого віку. 1 (54): 32-38]. doi: 10.15574/PS.2017.54.32.

15. Skyba VV, Rybalchenko VF, Ivanko OV, Demydenko YuH, Badakh VM, Bocharov VP. (2017). Khirurhichne likuvannia zapalnykh i spaikovykh protsesiv cherevnoi porozhnyny u pidlitkiv iz vykorystanniam strumenevoho hidroskalpelia. Zdorove rebenka. 12; 1: 68-74. [Скиба ВВ, Рибальченко ВФ, Іванько ОВ, Демиденко ЮГ, Бадах ВМ, Бочаров ВП. (2017). Хірургічне лікування запальних і спайкових процесів черевної порожнини у підлітків із використанням струменевого гідроскалпеля. Здоровье ребенка. 12 (1): 68-74]. URL: http:// nbuv.gov.ua/UJRN/Zd_2017_12_1_14.

16. Salomone DI, Saverio Mauro, Podda Fausto Catena. (2020) Diagnosis and treatment of acute appendicitis: 2020 update of the WSES Jerusalem guidelines. World Journal of Emergency Surgery. 15; 27. https://wjes.biomedcentral.com/articles/10.1186/ s13017-020-00306-3\#citeas

17. Zaremba YeKh, Zaremba VS, Rak NO, Hirniak OT, Zaremba OV, Burmai SV. (2020). Peryvezykalnyi infiltrat zhovchnoho mikhura z poshyrenniam na pidpechinkovyi prostir (klinichnyi vypadok). Praktykuiuchyi likar. 3-4: 10-15. [Заремба ЄX, Заремба ВС, Рак НО, Гірняк ОТ, Заремба ОВ, Бурмай СВ. (2020). Перивезикальний інфільтрат жовчного міхура з поширенням на підпечінковий простір (клінічний випадок). Практикуючий лікар. 3-4: 10-15].

\section{Відомості про авторів:}

Скиба Володимир Вікторович - д.мед.н., академік АНВШ, проф., директор «Центру хірургї» КНП «Київська міська клінічна лікарня №1», зав. каб. хірургічних хвороб №1 ПВНЗ «Київський медччний університет», зав. каб. хірургії, анестезіології та інтенсивної терапї ІПО НМУ імені О.О. Богомольия, Засл. діяч науки і техніки України, Лауреат державної премії України в галузі науки і техніки. Адреса: м. Київ, Харківське шосе, 121. https://orcid.org/0000-0002-7681-4217.

Рибальченко Василь Федорович - д.мед.н., проф., проф. каф. дитячої хірургії НУОЗ Украӥни імені П.Л. Шупика МОЗ України, проф. каф. хірургічних хвороб №1 ПВНЗ «Київський медичний університет». Адреса: м. Київ, вул. Дорогожицька, 9. https://orcid.org/0000-0002-1872-6948.

Іванько Олександр Вікторович - к.мед.н., дои., директор КНП «Київська міська клінічна лікарня №1», дои. каб. хірургіі, анестезіології та інтенсивної терапї Інституту післядипломної освіти НМУ імені О.О. Богомольия, дои. каф. хірургічних хвороб №1 ПВНЗ «Київський медичний університет», заслужений лікар Украӥни. Адреса: м. Київ, Харківське шосе, 121. https://orcid.org/0000-0003-0036-4675.

Борис Руслан Миколайович - д.мед.н., проф. каф. хірургічних хвороб №1 ПВНЗ «Киівський медичний університет». Адреса: м. Киӥв, вул. Дорогожицька, 9. https://orcid.org/0000-0002-2489-8682.

Дар Ясін Ахмед - дисертант каф. хірургічних хвороб №1 ПВНЗ «Київський медичний університет». Адреса: м. Київ, Харківське шосе, 121. httрs://огсіd. org/0000-0002-2353-238X.

Лисиия Василь Вікторович - асистент каф. хірургічних хвороб №1 ПВНЗ. «Київський медичний університет». Адреса: м. Київ, Харківське шосе, 121. https://orcid.org/0000-0001-5995-7251. 